\title{
Effects of Selection Tasks on Naming Emergence in Children
}

\author{
Efeitos de Tarefas de Seleção Sobre a Emergência de Nomeação em Crianças
}

\author{
Carmen Silvia Motta Bandini*, ${ }^{*}$, Ana Carolina Sella ${ }^{b}$, Lidia Maria Marson Postalli ${ }^{c}$, \\ Heloisa Helena Motta Bandini ${ }^{a} \&$ Emiliane Tayaara Pontes da Silva ${ }^{d}$ \\ ${ }^{a}$ Universidade Estadual de Ciências da Saúde de Alagoas, Alagoas, Brasil, ${ }^{b}$ University of Kansas, Kansas, USA, \\ ${ }^{c}$ Universidade Federal de São Carlos, São Carlos, Brasil \& ${ }^{d}$ Universidade Federal de Alagoas, Alagoas, Brasil
}

\begin{abstract}
The aim of the present work - which was divided into two studies - was to investigate if, from teaching selection tasks, naming responses would be emitted without direct teaching. Nine children aged between 7 and 12 participated in the study. In each study, 12 abstract pictures and 12 pseudo words were utilized. The procedures were comprised of six sessions that encompassed selection tasks (name-picture relations) and naming tests (picture-name relations). When a participant met $100 \%$ correct responses in selection tasks, (s)he was exposed to a naming test. The difference among the studies was the presentation of an echoic behavior pre-test of the pseudo words. The results indicated variability in the participants' naming performance.
\end{abstract}

Keywords: Language acquisition, naming, listener repertoire, speaker repertoire.

\begin{abstract}
Resumo
O presente trabalho, dividido em dois estudos, teve como objetivo verificar se a partir de tarefas de seleção, respostas de nomeação seriam emitidas sem ensino direto. Participaram ao todo nove crianças com idades entre 7 e 12 anos. Em cada estudo foram utilizadas 12 figuras abstratas e 12 pseudopalavras. Os procedimentos continham seis sessões compostas de tarefas de seleção (relações nome-figura) e de testes de nomeação (relações figura-nome). Alcançado desempenho de $100 \%$ de acerto nas tarefas de seleção, o participante era exposto ao teste de nomeação. A diferença entre os estudos foi a apresentação de um préteste de comportamento ecóico das pseudopalavras. Os resultados indicaram variabilidade no desempenho de nomeação dos participantes.

Palavras-chave: Aquisição da linguagem, nomeação, repertórios de ouvinte, repertórios de falante.
\end{abstract}

Among the various verbal behaviors that make up part of the repertoire that an individual must learn to establish communication in a verbal community is naming behavior. In Behavior Analysis, a definition of the naming response might start with Skinner's (1957/1992) definition of tact, even though the term naming was never used by this author. Skinner defines a tact "as a verbal operant in which a response of given form is evoked (or at least strengthened) by a particular object or event or property of an object or event" (p. 81-82). The word start was used above because some authors believe that naming responses may be more than just tacting an object, person, or event. As stated by Catania (1998/1999) and Horne and Lowe (1996), naming encompasses a tact, but is not limited to it. This is because tacting may be made only in

\footnotetext{
* Endereço para correspondência: Universidade Estadual de Ciências da Saúde de Alagoas, Curso de Fonoaudiologia, Rua Dr. Jorge de Lima, 113, Trapiche da Barra, Maceió, AL, Brasil 57010-300. E-mail: cbandini@superig.com.br
}

the presence of discriminative stimuli that evoke the response (Horne \& Lowe, 1996).

The learning of naming behaviors seems simple at first glance, especially when its development is understood from the perspective of typically developing children (Horne \& Lowe, 1996). However, when analyzing the number of studies and procedures that have sought to understand naming, its development, and how it can influence other verbal repertoires, its complexity can be seen. The myriad of studies that have been investigating naming responses can be roughly divided into two sets: one that discusses the broad topic of functional independence between the speaker and listener verbal repertoires, and one that specifies relations between specific verbal operants, such as mands and tacts (Almeida-Verdu et al., 2008a; Almeida-Verdu, dos Santos, de Souza, \& Bevilacqua, 2008b; Arntzen \& Almås, 2002; Carroll \& Hesse, 1987; Ferrari, Giacheti, \& de Rose, 2009; Guess, 1969; Guess, Sailor, Rutherford, \& Baer, 1968; G. Hall \& Sundberg, 1987; Miguel, Yang, Finn, \& Ahearn, 2009; Petursdottir, Carr, \& Michael, 2005; Ramirez \& Rehfeldt, 
2009; Sigafoos, Doss, \& Reichle, 1989; Sigafoos, Reichle, Doss, K. Hall, \& Pettitt, 1990; Toussaint \& Tiger, 2010).

In the first set of studies, the research focus is the functional independence/dependence between repertoires of speaker and listener. In a pioneer study, Guess et al. (1968) taught the use of plurals to a girl with intellectual disabilities who did not have this grammatical repertoire before the study. The rapid learning of the use of plurals through echoic training (vocal imitation) and reinforcement contingent on correct responses raised the question of whether the participant had already learned some grammatical behaviors as a listener and, through reinforcement, speaker behaviors were easily learned. In other words, the authors re-introduced the question already discussed in other studies: when learning a language, is it possible for the individual to learn grammar without having the ability to express or produce it?

To answer this question, Guess (1969) taught plurals to two participants with mental retardation, in order to specifically test the functional dependence or independence between repertoires of listening and speaking. The procedure was divided into the following phases: (a) pre-test; (b) receptive training, in which the participant was asked to indicate objects, single or in pairs (trials with the objects in the singular and trials with the objects in the plural), after hearing their names in the singular or plural, respectively, with probes for the behavior of production of the plural; (c) production training, in which the participants should produce the word in the plural or in the singular, depending on the sample used; (d) reversal of the receptive training phase, in which the behavior of indicating the singular comparison was reinforced when faced with the sample in the plu$\mathrm{ral}$; and (e) final training, in which the plural and singular conditions were again established as a pattern. The results indicated that the participants were not able to produce the words in the plural during the probes made in the receptive training phase. Thus, it was considered that the oral production of the words in the plural only occurred after the training for this condition, due to the fact that the repertoires of listening and speaking are functionally independent.

Other work that proposes independence between the repertoires of speaker and listener, represented by selection and vocal production behaviors, was performed by Almeida-Verdu et al. (2008a). These authors performed a series of studies with children with pre- and post-lingual sensorineural deafness who had received cochlear implants. Three studies intended to evaluate the performance of 10 children in these conditions using tasks involving equivalence relationships between pictures and dictated words with tests of naming. A fourth study worked with six other children in tasks involving equivalence stimulus between figures and tones released directly by electrical stimulation of the cochlea and, therefore, without the performance of naming tests. In the studies involving tasks of equivalence between pictures and dictated words, the results showed that although all of the children learned the relationship between the dictated word and the taught picture and the majority demonstrated the formation of equivalence classes, the naming tests performed at the end of the procedure had unsystematic results. The authors highlighted that the children demonstrated the same vocalization for the figures that were matched to the same dictated word, but the vocalization did not correspond point to point (the name was not exactly the required name) with the word, dictated in the teaching phase.

In a later study, Almeida-Verdu et al. (2008b) developed a procedure that aimed at verifying whether teaching word repetition (echoic repertoire) was a condition for the emergence of naming with point-to-point correspondence with heard words in deaf children who had received cochlear implants. The purpose of the study was to improve implanted participants' performance in naming tasks, seeking the conditions in which this population would present picture naming more accurately. This study was conducted with six children, 7 to 9 years of age. The procedure was divided into the following steps: (a) naming pre-test; (b) word echoic training and dictated word and picture relations; (c) equivalence class formation tests and (d) naming post-test. Echoic training was conducted in two different experimental conditions: before and during dictated word - pictures relations teaching. In the cases where the response was correct, a new trial was presented and in the cases where it was incorrect, the word was repeated by the experimenter, which provided orofacial clues to the participant. Regardless of success or failure, a new trial was presented. The results showed that high scores in the naming were obtained by the participants in both the teaching conditions. Thus, the repertoire of naming was considered to be functionally independent of the repertoire of listening, since it only appeared after the systematic teaching of vocal imitation.'

In another set of studies, the purpose was to verify the functional independence/dependence between verbal operants. Carroll and Hesse (1987), for example, tested two conditions for the teaching of new verbal responses in children with typical development. One condition employed the alternating teaching of mand and of tact and the other condition employed only the teaching of tact. The stimuli used were toys (e.g. toy vehicles, animals or games). In the alternating mand-tact training, the first part of each trial was a command, for example, "Make a

" (the pieces were available on table) (p. 59); and the second part of the trial was a tact, the object was placed on the table and the experimenter said "This is a car. What is this?" (p. 59). For the tact training, only tact trials were used as previously described. All six participants performed the two training conditions starting in reverse 
order in the two phases of the procedure. The results indicated that in the condition of teaching that alternates mand-tact trials, the children required fewer trials than those in the condition that used only the teaching of tact. The authors suggest that the learning through both contingencies facilitated acquisition. Arntzen and Almås (2002) replicated and extended the results obtained in the study by Carroll and Hesse (1987), including participants with typical and atypical development.

Petursdottir et al. (2005) investigated the functional independence between mands and tacts in five typically developing preschool children, using assembly tasks with cubes and puzzles. The effects of training on the untrained operant were evaluated in multiple tests: testing one verbal operant after teaching another one. The children were assigned to different training conditions: either tact and mand training or just tact training. During tact tasks, the participant said the name of each of the four pieces presented by the experimenter, after the question "What is this?" If the child answered correctly, the experimenter praised the child and gave him/her a sticker. If the child answered incorrectly or did not give a response after 5 seconds, the experimenter vocally presented the correct answer and repeated the trial. In the mand task, the experimenter provided three of the four parts of an assembly game and instructed the child to assemble them. After putting the pieces together, the experimenter asked the child "What do you need?" and the child said the name of the piece. If the child responded correctly with the name of the missing piece, the experimenter delivered that piece without providing any other consequences such as praise or smiles. After receiving the piece, the child needed to complete the puzzle. At the end of the task, the experimenter praised the participant and gave him/her a sticker. If the child did not emit a vocal response after 5 seconds, the experimenter vocally presented the correct answer and the trial was repeated. If the child emitted an incorrect vocal response and/or named a piece that was already on the table, the experimenter showed the piece and presented the correct vocal response, then the trial was repeated. The results showed that after the mand training, four children emitted tact responses under test conditions, while the effects of the tact training differed among the participants. The authors highlight that the proposed tasks should be compatible with the age group of the children and the condition appropriate for the establishing operation for the mand responses may have favored the control of responses in the different operants.

Three studies investigated the relationship between tacts and mands through the manipulation of prompts. In one of these studies, G. Hall and Sundberg (1987) evaluated whether the teaching of tacts could generate the emission of mands. The study participants were two deaf students with severe intellectual disabilities. They were taught chains of behaviors involving objects and actions (e.g. open a can of fruit: objects - can opener, tin; action open). When teaching tact topographies two procedures were used: prompts for the tact ("What is this?") and imitation prompts ("What do you need?"). The results showed that the topographies of mand did not occur after the teaching of tact. After the direct teaching of four mands, the participants maintained the behavior for the taught objects and began to give responses to objects not taught. In another study, Sigafoos et al. (1989) investigated the procedures for the development of mands and tacts with three learners with severe developmental difficulties. First tact was taught and mand tested for items of food/ drink and utensils used with these items. The results suggested that responses acquired with the tact were not acquired with the mand. "Spontaneous" mands were developed using the procedure of transference of stimulus control, in which the mand was established via the establishing operation. After training for some items in both the operants (tact and mand), a significant transference was obtained between response classes for objects not directly trained. Finally, Sigafoos et al. (1990) verified that two adults with Down Syndrome and intellectual disabilities presented mand responses to two out of three utensils after the tact training. The results suggest that the transfer of tacts to conditioned establishing operations may have been facilitated by the previous development of a minimum mand repertoire.

Considering the studies presented, it was verified that the discussion between functional dependence and independence is complex due to the fact that many studies involve the manipulation of distinct variables and use different types of procedures, such as alternating training, echoic training and training in both operants for some items. At the same time, these studies raise possible discussions regarding the minimum repertoire of the participants and aspects related to the special characteristics of some of them, for example, intellectual and hearing disability.

From these questions, the present work developed two studies to be presented here. Both studies aimed to verify whether from the tasks involving repertoires of the listener (called selection tasks), responses involving repertoires of speaker (called naming tasks) would be emitted without direct teaching.

In both studies, the participants were taught the relationship between abstract figures and pseudowords (nonsense words). In these tasks the participants were asked to point to the picture that corresponded to the word dictated. If the participants were able to say the name of the pictures after they had achieved the performance criterion in the selection tasks, this result would suggest functional dependence between the repertoires of listener and speaker. On the other hand, if the participants were unable to say the name of the following figures after pointing to it, the data would 
Bandini, C. S. M., Sella, A. C., Postalli, L. M. M., Bandini, H. M. \& Silva, E. T. P. (2012). Effects of Selection Tasks on Naming Emergence in Children.

provide more evidence for those studies that suggest there is functional independence between the repertoires of speaker and listener. The difference between the two studies was the inclusion, in Study 2, of an echoic behavior pre-test of the pseudowords to be taught, which had the performance of $100 \%$ correct responses as a requirement for participation in the procedure, ensuring that the participants were able to pronounce the pseudowords in question.

\section{Method}

Study 1

\section{Participants}

The study participants were four children, ages between 7 years 7 months and 12 years 2 months, at the beginning of the study. All the selected children were evaluated using the ABFW language test (Andrade, Befi-Lopes, Fernandes, \& Wertzner, 2004) and none of them presented phonetic and/or phonological exchanges. Any child who presented phonetic and/or phonological exchanges would have been excluded from the study.

Table 1

Characterization of the Participants of Study 1 By Gender, Age (Years and Months at the Beginning of the Study) and School Grade

\begin{tabular}{cccc}
\hline Participants & Gender & Age & School grade \\
\hline P1 & F & 8 years and 10 months & $2^{\text {nd }}$ year $\left(1^{\text {st }}\right.$ grade $)$ \\
P2 & M & 12 years and 3 months & $5^{\text {th }}$ year $\left(4^{\text {th }}\right.$ grade $)$ \\
P3 & M & 10 years and 11 months & $5^{\text {th }}$ year $\left(4^{\text {th }}\right.$ grade $)$ \\
P4 & M & 7 years and 7 months & $2^{\text {nd }}$ year $\left(1^{\text {st }}\right.$ grade $)$ \\
\hline
\end{tabular}

\section{Experimental Stimuli}

The stimuli used were 12 dictated names (pseudowords) and 12 abstract pictures. The dictated names were comprised of three syllables that were regular and simple (consonant-vowel syllables, with no Portuguese language complexities). These dictated names were used as sample stimuli in the selection tasks. The abstract pictures came from the Dube and Hiris' (1999) program and were used as comparison stimuli in selection tasks and as sample stimuli in naming tasks.

\section{Environmental and Experimental Materials}

The study was conducted at the Núcleo Informatizado de Estudos da Linguagem, located in the Universidade Estadual de Ciências da Saúde de Alagoas (UNCISAL), with the approval of the Ethics Committee under protocol No. 1163 (CEP-UNCISAL).

As previously mentioned, for the selection of the participants the ABFW language test (Andrade et al., 2004) was used. For this study only the phonology evaluation, using the picture naming method, was employed. This test consists of 34 pictures arranged in laminated cards measuring $12 \mathrm{~cm} \mathrm{X} 21 \mathrm{~cm}$. The examiner presents the pictures to the child so that he/she has a full view of the picture printed on each card and asks him/her to say the name of the picture shown. The sessions were recorded using a digital voice recorder for later analysis.

For the data collection and analysis, the software, "Aprendendo a ler em pequenos passos" (Rosa Filho, de Rose, de Souza, Hanna, \& Fonseca, 1998) was used, adapted for the performance of the tasks described in the general procedure. This software generates output files, recording the stimuli presented and the responses emitted by the participants for each trial. A digital voice recorder was used to record the participants' oral responses.

\section{Inter-observer Agreement (IOA)}

IOA for naming tasks was calculated by either using the digital voice recordings of the sessions or through direct observation in the sessions. Concerning the digital recording, a second observer listened to the recordings after the sessions and registered the responses heard. Regarding the direct observation, the second observer sat with his back to the participant and to the first observer and recorded the naming responses emitted by the participants in the session. In both cases, the recordings of the first observer were compared to those of the second observer. IOA was calculated for 22 out of the 24 sessions by adding the trials in which there was agreement between the observers, dividing it by the total number of trials, and multiplying the result by 100 (Cooper, Heron, \& Heward, 2007). For P1 (DA), the index calculated was $95 \%$; for $\mathrm{P} 2 \mathrm{(TH})$ it was $100 \%$; for P3 (NI) it was $87 \%$; and for $\mathrm{P} 4(\mathrm{BE})$ it was $100 \%$.

\section{Experimental Design}

A simultaneous multiple baseline between participants and successive multiple baseline across pairs of stimuli design was used (Kelly, 1980). Each participant was taught, using pairs of stimuli, twelve conditional discriminations between dictated names and abstract figures. After teaching each pair of conditional discriminations, the 
naming test was performed for the abstract pictures, provided that the participant obtained $100 \%$ of correct responses in the selection tasks.

In this design, the participant had two naming opportunities, one for each of the pictures, if they responded correctly in at least eight trials in the selection tasks. The maximum number of blocks presented with each pair of stimuli was three blocks of selection and naming tasks presented in an interspersed manner.

\section{General Procedure}

Teaching conditional discriminations between dictated words and figures (stimulus selection tasks) tasks were composed of eight trials, four trials for each sample stimulus. The naming test tasks were composed of two trials, one for each picture. Selection tasks and naming tasks relative to a pair of stimuli formed one session. Only one session per day was presented to each participant.

The performance criterion in each task was $100 \%$ correct responses. If the participant achieved $100 \%$ accuracy in the selection and naming tasks or they reached the maximum number of re-presentations of the tasks, a new pair of stimuli was taught in the next session. Figure 1 shows an illustrative screen of one of the selection tasks (left panel) and one of the naming tasks (right panel).

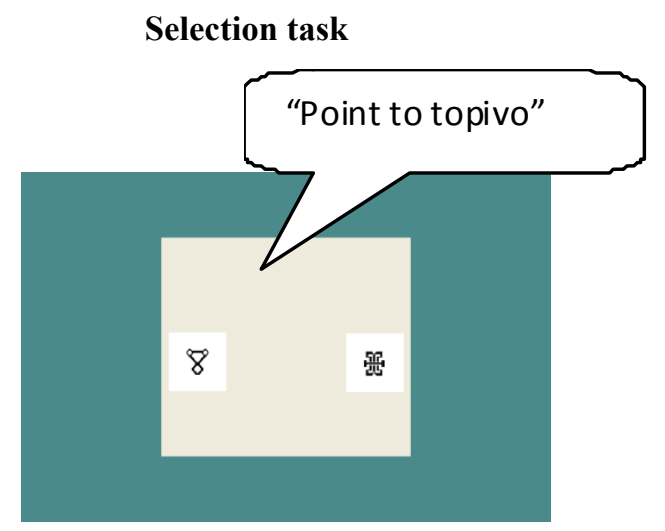

\section{Naming Task}

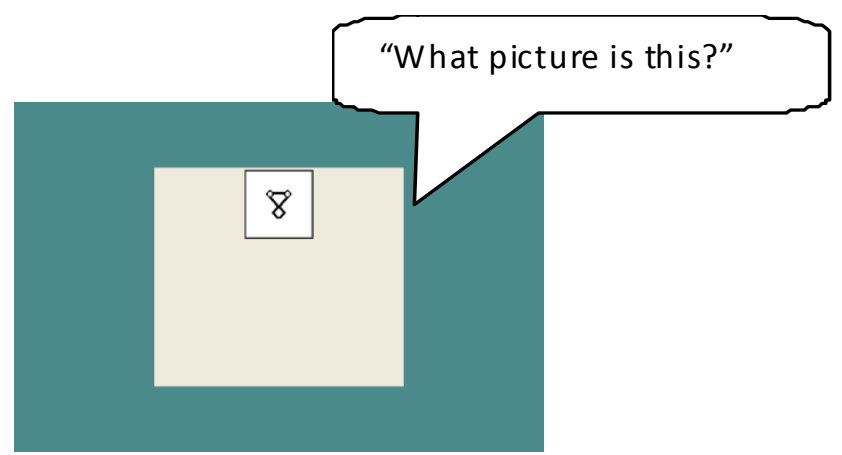

Figure 1. Illustrative screen of one trial of the selection tasks (left panel) and one trial of the naming tasks (right panel).

\section{Tasks of Teaching Conditional Discriminations (Selection Tasks)}

In a selection trial, the instruction "Point to the (name of the picture)" was presented. At the same time, two pictures were presented simultaneously on the bottom part of the screen. The oral instruction continued to be presented every 5 seconds if the participant did not choose one of the comparison stimuli. A choice consisted of the child clicking the computer mouse on one of the two comparison stimuli (i.e., abstract pictures).

Correct responses resulted in the presentation of computer sounds, such as sounds of applause and praise, in the intertrial interval and in the presentation of the next trial. Incorrect responses resulted in the presentation of a correction trial in which the comparison stimuli were re-presented in the same position as in the previous trial and the instruction "Point to the (name of the picture)" was repeated. Correction trials were repeated until the participant emitted a correct response as experimentally defined. Correction trials were not counted as teaching trials, therefore, in the blocks in which there were incorrect selection responses, the total number of trials was higher than the original eight. The blocks of eight trials of selection tasks could be repeated up to three times in the same session. The repetitions of the blocks occurred as a result of either one of two factors: (a) every time it was necessary to present one or more correction trials in the selection tasks or (b) if the participant emitted incorrect responses during naming tasks. If the participant did not achieve the performance criteria established after the third representation of the selection tasks, the tasks for this stimulus pair were ended. The next day, a new session with a new pair of stimuli was presented.

\section{Naming Tasks}

In naming tasks, each picture was presented individually in the center of the computer screen. Simultaneously, the question "What picture is this?" was presented. The child was asked to say the name of the picture. Correct or incorrect responses were not followed by programmed consequences. Incorrect responses were recorded by the experimenter on the computer for later analysis.

\section{Study 2}

\section{Participants}

The study participants were five children, ages between 8 years 1 month and 10 years 9 months, at the beginning of the study. All the selected children were evaluated using the ABFW language test (Andrade et al., 2004) and none of them presented phonetic and/or phonological exchanges. Again, the presentation of any phonetic and/or phonological exchange was an exclusion criterion of the study. 
Bandini, C. S. M., Sella, A. C., Postalli, L. M. M., Bandini, H. M. \& Silva, E. T. P. (2012). Effects of Selection Tasks on Naming Emergence in Children.

Table 2

Characterization of the Participants of Study 2 According to Gender, Age (Years and Months at the Beginning of the Study) and School Grade

\begin{tabular}{cccc}
\hline Participants & Gender & Age & School grade \\
\hline P5 & M & 9 years and 3 months & $3^{\text {rd }}$ year $\left(2^{\text {nd }}\right.$ grade $)$ \\
P6 & F & 10 years and 9 months & $3^{\text {rd }}$ year $\left(2^{\text {nd }}\right.$ grade $)$ \\
P7 & M & 9 years and 5 months & $3^{\text {rd }}$ year $\left(2^{\text {nd }}\right.$ grade $)$ \\
P8 & M & 8 years and 1 month & $2^{\text {nd }}$ year $\left(1^{\text {st }}\right.$ grade $)$ \\
P9 & M & 9 years and 6 months & $3^{\text {rd }}$ year $\left(2^{\text {nd }}\right.$ grade $)$ \\
\hline
\end{tabular}

Since pseudo words might complicate naming tasks with regards to word pronunciation, an echoic behavior pre-test of these words was presented to all participants: the correct pronunciation of all experimental words was considered a requirement for participation in the study.

For the echoic test 40 pseudowords were used, which were developed for the Teste Brasileiro de Repetição de Pseudopalavras (Santos \& Bueno, 2003), with the 12 words that would be taught in this study added at random. The pseudowords were presented in a quiet room, one by one to the participant and were repeated immediately after the presentation by the experimenter. The evaluation was recorded on digital voice files for later analysis.

The remaining steps of the procedure were rigorously identical to the procedure of Study 1.

\section{$I O A$}

IOA was calculated in the same manner as in Study 1. There was a second observer in 24 of the 30 sessions. For P5 (PA), the calculated index was $93 \%$; for P6 (CR) $100 \%$; for P7 (WI) 75\%; for P8 (PE) $87 \%$ and for P9 (OJ) the index was $75 \%$.

\section{Results and Discussion}

The aim of the study was to verify whether from selection tasks, naming responses would be emitted without direct teaching. Figures 2 and 3 show the percentage of correct responses in selection blocks (white bars) and naming blocks (black triangles) at each step, for each of the participants in Studies 1 and 2, respectively. Overall, it was found that most subjects were exposed to repeated blocks of selection tasks in the majority of the sessions. This repetition occurred for two reasons: in some cases, the participant did not reach the $100 \%$ accuracy criterion in the selection block; in other cases, the participant did not correctly name the word and, therefore, performed the selection block again.

Although there was the presentation of errors in the selection blocks, the number of errors was commonly equal to one, i.e. one incorrect response in eight trials presented. Regarding the naming of the pictures, the results obtained in the two studies show that the participants named abstract pictures after performing the selection task, but there was variability in the performance throughout the tasks. Such variability can be found in the fact that, among the total number of pictures that were named for each child, no child obtained a $100 \%$ success rate in the naming, i.e. a picture was not named correctly every time it came to be named. As illustrated in Figure 2 , in Study 1, two participants (P1 and P2) correctly named nine pictures and two participants ( $\mathrm{P} 3$ and $\mathrm{P} 4)$ named five and four of the twelve pictures, respectively. As shown in Figure 3, in Study 2, participants P5, P6 and P7 named ten, eight and seven pictures, respectively, and P8 and P9 correctly named five pictures each.

Overall, there was no difference in performance in selection tasks, nor in naming tasks when comparing participants' performance in both studies: $100 \%$ accuracy in the echoic behavior pre-test did not guarantee accurate performance. In other words, the results obtained suggest that accurate performance in the echoic pre-test was not a sufficient variable for predicting the emergence of naming, since Study 2 participants showed no significant differences in performance when compared to Study 1 participants. In echoic behavior, the response of saying a word is under the control of a spoken word; in the naming tasks of the present studies, the naming response should was controlled by the abstract picture. The child may be able to say the word correctly When the dictated word was presented (echoic behavior), but not able to reproduce the same word under the control of the abstract figure (tact). The ability to emit an echoic response when the pseudo-words were presented may be necessary for the emission of the naming responses, as shown in the study by Almeida-Verdu et al. (2008b). However, the results of these studies show that such performance was not sufficient to guarantee correct naming responses. These data suggest that future studies should search for other variables that are necessary and sufficient for the emission of naming responses.

The results of the present study cannot be considered conclusive when considering the functional independence or dependence of verbal repertoires: participants emitted 


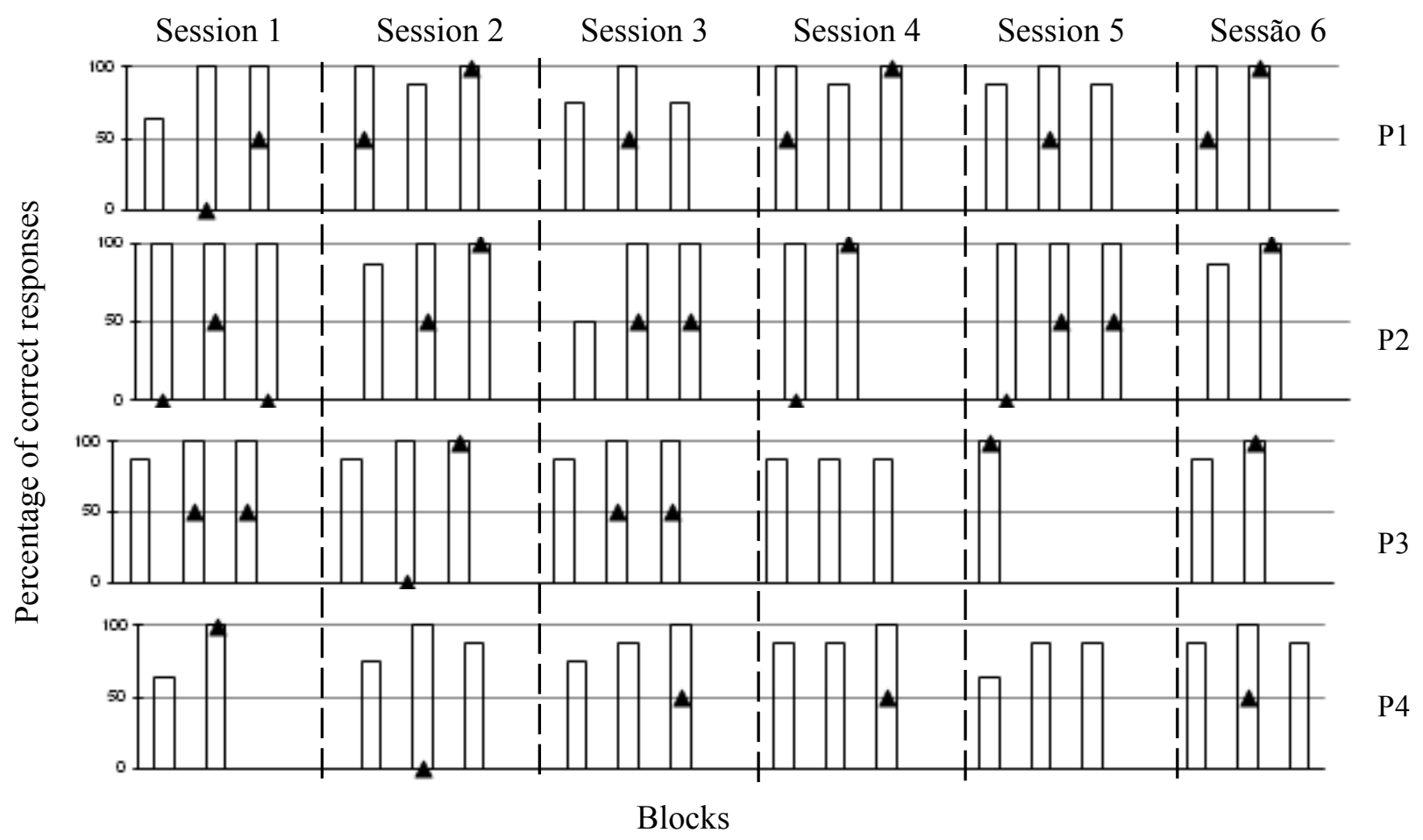

Figure 2. Percentage of correct responses in selection (white bars) and naming (black triangle) blocks in each session for each of the participants of Study 1.

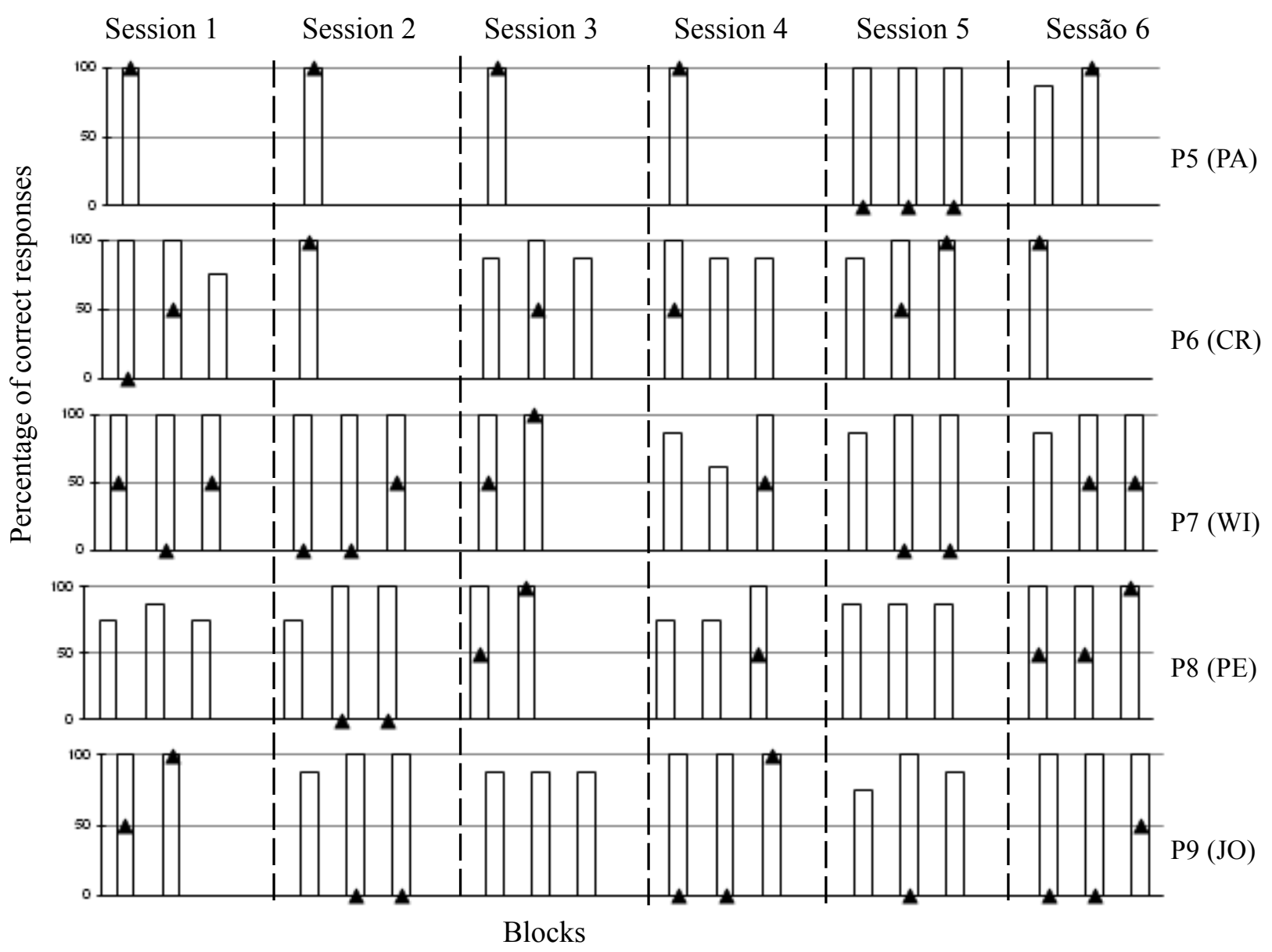

Figure 3. Percentage of correct responses in selection (white bars) and naming (black triangle) blocks in each session for each of the participants of Study 2 . 
responses that could be said to show functional dependence between speaker and listener repertoires there was emergence of naming - and they also emitted responses that did not show such emergence (errors in the naming responses).

While there may be arguments that the results obtained indicate that the selection tasks did not lead to the emission of naming responses, it is important to take into account the results shown in Figures 2 and 3: P1 correctly named at least one of the pictures in $100 \%$ of the sessions; participants P2, P3, P4 (of Study 1) and P5, P6 and P7 (of Study 2) correctly named at least one picture in $83.5 \%$ of the sessions and P8 and P9 (of Study 2) correctly named at least one of the figures in at least $66.6 \%$ of the sessions. Such correct naming responses were issued with $100 \%$ point-to-point correspondence. This emission is unlikely to have been random, because these responses did not involve forced choices, such as in the case of the selection tasks, and there was no emission of the same name for different stimuli (Greer, Stolfi, Chavez-Brown, \& RiveraValdes, 2005). It is important to remember that the results discussed here do not necessarily refer to the performance of the participants after the third block of selection tasks. Tables 3 and 4 present the naming of the figures for the participants of Study 1 and Study 2, respectively. As can be observed, when emitting naming responses, the participants always gave different responses to the different pictures.

It is important to remember that the results discussed here do not necessarily refer to participants' performance after the third block of selection tasks. Tables 3 and 4 present picture naming performance in Study 1 and Study 2 , respectively. As it can be observed, when emitting naming responses, the participants emitted different responses to the different pictures. For example, pictures from Session 1 ("topivo" and "duveca") were named "dupico" and "tupeca", respectively, and the picture "rudafa", the child pronounced "rudava". When analyzing the point-to-point correspondence throughout the successive naming trials for each participant, it was observed that, for the pictures that were re-exposed to the naming trials, there was variability in the performances of the participants. For example, P1 increased her point-to-point correspondence over the course of the reexposure: for the word "topivo", the participant said "dutopivo" and "duveca" and finally "topido", for the word "duveca" P1 said "topigo" and then gave the correct name. In other words, there was a greater point-to-point correspondence in the last words emitted by this participant. For P2, P3, P5, P6, P7, P8 and P9 the data are less consistent: $\mathrm{P} 2$ increased the correspondence in relation to six words, however, for four words the correspondence decreased or remained the same when there were repeated naming trials; P3 increased the correspondence in two words and remained the same in four; there was one increase for P5 and one decrease in the percentage of point by point correspondence; $\mathrm{P} 6$ increased the correspondence in three of the four words that were renamed; for P7 there were four increases of correspondence, four remained unchanged and two pointto-point correspondences decreased; there were three increases for $\mathrm{P} 8$, two correspondences remained the same and one decreased; and for P9, there were increases in four correspondences, two remained the same and one decreased. There was no re-exposure to the naming trials for P4. The data suggest that the teaching procedure employed in this study (selection blocks with eight trials and the maximum of three repetition blocks per session) was not enough to achieve $100 \%$ correct responding in picture naming tasks, with $100 \%$ point-to-point correspondence. However, there was a number of naming responses that had varying degrees of correspondence. This suggests that this teaching procedure, with some variations, may facilitate the emergence of naming, without direct teaching, from the selection tasks. Therefore, these results suggest that the amount of training in dictated word-picture relations might be an important variable to be further investigated (Arntzen \& Almås, 2002; Carroll \& Hesse, 1987; G. Hall \& Sundberg, 1987; Nuzzolo-Gomez \& Greer, 2004; Petursdottir et al., 2005; Sigafoos et al., 1989; Sigafoos et al., 1990; Twyman, 1996).

The data obtained suggest that the structure of teaching employed (selection blocks with eight trials and the maximum of three repetition blocks per session) was not enough for there to be $100 \%$ naming of the pictures with $100 \%$ point-to-point correspondence. However, there was a considerable number of naming responses with varying degrees of correspondence, which suggests that this teaching procedure, with some variations, may favor naming, without direct teaching, from the selection tasks. Therefore, these results suggest that the amount of training in the word-picture relationship can be an important variable to be investigated.

Different procedures have been used to investigate the relation between speaker and listener repertoires. These procedures range from establishing operations manipulation (Nirgudkar, 2005) to other antecedent stimuli manipulation, which involve procedures such as incidental teaching and stimulus equivalence (Luciano, Becerra, \& Valverde, 2007; Randell \& Remington, 2006). Among these, the most common are those that involve stimulus equivalence (Almeida-Verdu et al., 2008a; Almeida-Verdu et al., 2008b). The search for controlling variables for these repertoires, which may lead to the emergence of naming from selection teaching, should be used in the arsenal of procedures already developed for behavioral analysis, creating new ways to investigate this issue. Future studies should primarily seek to perform a synthesis of the previous studies, as such studies can indicate the variables involved in the acquisition and/or the emergence of the naming repertoire. 
Table 3

Naming of thePictures for the Participants of Study 1. Tics Indicate Correct Naming Responses; Dashes Indicate that the Naming Block was not Performed; Words Indicate Incorrect Naming

\begin{tabular}{|c|c|c|c|c|c|c|c|c|c|c|c|c|c|}
\hline \multirow{3}{*}{ 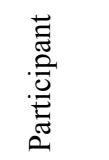 } & \multirow{3}{*}{$\frac{y}{0}$} & \multicolumn{2}{|c|}{ Session 1} & \multicolumn{2}{|c|}{ Session 2} & \multirow{2}{*}{\multicolumn{2}{|c|}{$\begin{array}{c}\text { Session } 3 \\
\text { Sumodi Rinedo }\end{array}$}} & \multicolumn{2}{|c|}{ Session 4} & \multicolumn{2}{|c|}{ Session 5} & \multirow{2}{*}{\multicolumn{2}{|c|}{$\begin{array}{c}\text { Session } 6 \\
\text { Funiju Paleno }\end{array}$}} \\
\hline & & Topivo & Duveca & Rudafa & Lobivu & & & Rejobe & Sojita & Ramuga & Roguvi & & \\
\hline & & & 哭 & $\theta$ & 80 & B & & 8 & D & l & 3 & 2 & ט. \\
\hline \multirow[t]{3}{*}{ P1(DA) } & 1 & - & - & $\checkmark$ & Lobigu & - & - & $\checkmark$ & Don't & - & - & $\checkmark$ & Palena \\
\hline & 2 & $\begin{array}{c}\text { Dutopivo/ } \\
\text { Duveca }\end{array}$ & Topigo & - & - & $\checkmark$ & $\begin{array}{l}\text { Rimedi/ } \\
\text { Quimedo }\end{array}$ & - & - & $\checkmark$ & Robivi & $\checkmark$ & $\checkmark$ \\
\hline & 3 & Topido & $\checkmark$ & $\checkmark$ & $\checkmark$ & - & - & $\checkmark$ & $\checkmark$ & - & - & & \\
\hline \multirow[t]{3}{*}{ P2(TH) } & 1 & Dupico & Tupeca & - & - & - & - & Erejobe & Esqueceu & $\begin{array}{l}\text { Don't } \\
\text { know }\end{array}$ & Goguvi & - & - \\
\hline & 2 & Tupico & $\checkmark$ & Ludafa & $\checkmark$ & $\checkmark$ & Simedo & $\checkmark$ & $\checkmark$ & Raguvi & $\checkmark$ & $\checkmark$ & $\checkmark$ \\
\hline & 3 & Tupigo & Tupeca & $\checkmark$ & $\checkmark$ & $\checkmark$ & Sinedo & & & $\begin{array}{l}\text { Don't } \\
\text { know }\end{array}$ & $\checkmark$ & & \\
\hline \multirow[t]{3}{*}{$\mathrm{P} 3(\mathrm{NI})$} & 1 & - & - & - & - & - & - & - & - & $\checkmark$ & $\checkmark$ & - & - \\
\hline & 2 & Topigo & $\checkmark$ & Rodafa & Lobivada & $\checkmark$ & Vimedo & - & - & & & $\checkmark$ & $\checkmark$ \\
\hline & 3 & Topigo & $\checkmark$ & $\checkmark$ & $\checkmark$ & $\checkmark$ & Vimedo & - & - & & & & \\
\hline \multirow[t]{3}{*}{ P4(BE) } & 1 & - & - & - & - & - & - & - & - & - & - & - & - \\
\hline & 2 & $\checkmark$ & $\checkmark$ & Lobivu & Lodivu & - & - & - & - & - & - & $\checkmark$ & Palerda \\
\hline & 3 & & & - & - & $\checkmark$ & Sinedo & $\checkmark$ & Sogia & - & - & - & - \\
\hline
\end{tabular}

Table 4

Naming of thePictures for the Participants of Study 2. Tics Indicate Correct Naming Responses; Dashes Indicate that the Naming Block was not Performed; Words Indicate Incorrect Naming

\begin{tabular}{|c|c|c|c|c|c|c|c|c|c|c|c|c|c|}
\hline \multirow{3}{*}{ 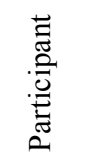 } & \multirow{3}{*}{$\frac{y}{0}$} & \multicolumn{2}{|c|}{ Session 1} & \multicolumn{2}{|c|}{ Session 2} & \multirow{2}{*}{\multicolumn{2}{|c|}{$\begin{array}{c}\text { Session } 3 \\
\text { Sumodi Rinedo }\end{array}$}} & \multicolumn{2}{|c|}{ Session 4} & \multicolumn{2}{|c|}{ Session 5} & \multirow{2}{*}{\multicolumn{2}{|c|}{$\begin{array}{c}\text { Session } 6 \\
\text { Funiju Paleno }\end{array}$}} \\
\hline & & Topivo & Duveca & a Rudafa & Lobivu & & & Rejobe & Sojita & Ramuga & Roguvi & & \\
\hline & & 9 & 墨 & $\theta$ & 8 & (1) & L & 8 & 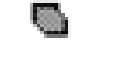 & Q & 8 & थ' & ". \\
\hline \multirow[t]{3}{*}{ P5(PA) } & 1 & $\checkmark$ & $\checkmark$ & $\checkmark$ & $\checkmark$ & $\checkmark$ & $\checkmark$ & $\checkmark$ & $\checkmark$ & Ramun & Roguifi & - & - \\
\hline & 2 & & & & & & & & & Ramunga & Rogufi & $\checkmark$ & $\checkmark$ \\
\hline & 3 & & & & & & & & & Ralmunga & a Rogufi & & \\
\hline \multirow[t]{3}{*}{ P6(CR) } & 1 & Duvico & Topázio & $\checkmark$ & $\checkmark$ & - & - & $\checkmark$ & Suchita & - & - & $\checkmark$ & $\checkmark$ \\
\hline & 2 & Topizo & $\checkmark$ & & & Sumodge & $\checkmark$ & - & - & $\checkmark$ & $\begin{array}{c}\text { Rogugue/ } \\
\text { Rogu }\end{array}$ & & \\
\hline & 3 & - & - & & & - & - & - & - & $\checkmark$ & Roguve & & \\
\hline \multirow[t]{3}{*}{ P7(WI) } & 1 & Tupido & $\checkmark$ & Rudava & Rudeva & $\checkmark$ & Don't & - & - & - & - & - & - \\
\hline & 2 & $\begin{array}{l}\text { Don't } \\
\text { know }\end{array}$ & $\begin{array}{l}\text { Don't } \\
\text { know }\end{array}$ & Rudava & Rudeva & $\checkmark$ & $\checkmark$ & - & - & Ravuga & Rovuga & $\checkmark$ & Baleno \\
\hline & 3 & $\checkmark$ & Rufea & Rudava & $\checkmark$ & & & Seijita & $\checkmark$ & Ravuga & Rogugui & $\checkmark$ & Bolinu \\
\hline \multirow[t]{3}{*}{ P8(PE) } & 1 & - & - & - & - & $\checkmark$ & $\begin{array}{l}\text { Don’t } \\
\text { know }\end{array}$ & - & - & - & - & $\checkmark$ & $\begin{array}{l}\text { Don't } \\
\text { know }\end{array}$ \\
\hline & 2 & - & - & Don't know & N Lovibu & $\checkmark$ & $\checkmark$ & - & - & - & - & $\checkmark$ & Valeno \\
\hline & 3 & - & - & Rudava & Rubiva & & & $\checkmark$ & $\begin{array}{l}\text { Sogiza/ } \\
\text { on't know }\end{array}$ & - & - & $\checkmark$ & $\checkmark$ \\
\hline \multirow[t]{3}{*}{ P9(JO) } & 1 & $\checkmark$ & Vida & - & - & - & - & Sejobe & Sejobe & - & - & Funigu & Faleno \\
\hline & 2 & $\checkmark$ & $\checkmark$ & $\begin{array}{l}\text { Don't } \\
\text { know }\end{array}$ & Cambigu & - & - & $\begin{array}{l}\text { Don’t } \\
\text { know }\end{array}$ & $\begin{array}{l}\text { Don't } \\
\text { know }\end{array}$ & Rogofe & Rogobe & Faleno & Funiju \\
\hline & 3 & - & - & Lovada & $\begin{array}{l}\text { Don't } \\
\text { know }\end{array}$ & - & - & $\checkmark$ & $\checkmark$ & - & - & $\checkmark$ & Paneju \\
\hline
\end{tabular}


Bandini, C. S. M., Sella, A. C., Postalli, L. M. M., Bandini, H. M. \& Silva, E. T. P. (2012). Effects of Selection Tasks on Naming Emergence in Children.

\section{References}

Almeida-Verdu, A. C., dos Santos, S. L. R., de Souza, D. G., \& Bevilacqua, M. C. (2008b). Ouvir e falar: Repertório de comunicação em surdos que receberam o implante coclear. In S. Z. de Pinho \& J. R. Saglietti (Eds.), Revista Eletrônica de Núcleos de Ensino (pp. 902-913). Bauru, SP: Editora da Universidade Estadual de São Paulo.

Almeida-Verdu, A. C., Huziwara, E. M., de Souza, D. G., de Rose, J. C., Bevilacqua, M. C., Lopes, J., Jr., et al. (2008a). Relational learning in children with deafness and cochlear implants. Journal of the Experimental Analysis of Behavior, 89(3), 407-424.

Andrade, C. R. F., Befi-Lopes, D. M., Fernandes, F. D. M., \& Wertzner, H. F. (2004). ABFW - Teste de linguagem infantil nas áreas de fonologia, vocabulário, fluência e pragmática. Carapicuiba, SP: Pró-Fono.

Arntzen, E., \& Almås, I. K. (2002).Effects of mand-tact versus tact-only training on the acquisition of tacts. Journal of Applied Behavior Analysis, 35, 419-422.

Carroll, R. J., \& Hesse, B. E. (1987). The effect of alternating mand and tact training on the acquisition of tacts. The Analysis of Verbal Behavior, 5, 55-65.

Catania, A. C. (1999). Aprendizagem: Comportamento, linguagem e cognição (D. G. de Souza, Coord. Trad.) Porto Alegre, RS: Artes Médicas. (Original work punlished 1998)

Cooper, J. O., Heron, T. E., \& Heward, W. L. (2007). Applied behavior analysis ( $2^{\text {nd }}$ ed.). Upper Saddle River, NJ: Pearson.

Dube, W. V., \& Hiris, E. J. (1999). MTS software documentation [Computer software and manual]. Waltham, MA: E. K. Shriver Center.

Ferrari, C., Giacheti, C. M., \& de Rose, J. C. C. (2009). Procedimentos de emparelhamento com o modelo e possíveis aplicações na avaliação de habilidades de linguagem. Salusvita, 28(1), 85-100

Greer, R. D., Stolfi, L., Chavez-Brown, M., \& Rivera-Valdez, C. (2005). The emergence of the listener to speaker component of naming in children as a function of multiple exemplar instruction. The Analysis of Verbal Behavior, 21, 123-134

Guess, D. (1969). A functional analysis of individual differences in generalization between receptive and productive language in retarded children. Journal of Applied Behavior Analysis, 2, 55-64

Guess, D., Sailor, W., Rutherford, G., \& Baer, D. M. (1968). An experimental analysis of linguistic development: The productive use of the plural morpheme. Journal of Applied Behavior Analysis, 1, 297-306.

Hall, G., \& Sundberg, M. L. (1987). Teaching mands by manipulating conditioned establishing operations. The Analysis of Verbal Behavior, 5, 41-53.

Horne, P. J., \& Lowe, C. F. (1996). On the origins of naming and other symbolic behavior. Journal of the Experimental Analysis of Behavior, 65, 185-241.

Kelly, J. A. (1980). The simultaneous replication design: The use of a multiple baseline to establish experimental control in single group social skills treatment studies. Journal of Behavior Therapy and Experimental Psychiatry, 11(3), 203207. doi: 10.1016/0005-7916(80)90028

Luciano, C., Becerra, I. G., \& Valverde, M. R. (2007). The role of multiple-exemplar training and naming in establishing derived equivalence in an infant. Journal of the Experimental Analysis of Behavior, 87, 349-365.
Miguel, C. F., Yang, H. G., Finn, H. E., \& Ahearn, W. H. (2009). Establishing derived textual control in activity schedules with children with autism. Journal of Applied Behavior Analysis, 42(3), 703-709.

Nirgudkar, A. S. (2005). The relative effects of the acquisition of naming and the multiple exemplar establishing operation experience on the acquisition of the transformation of establishing operations across mands and tacts. (Unpublished master's thesis). Columbia University, New York, USA.

Nuzzolo-Gomez, R., \& Greer, R. D. (2004). Emergence of untaught mands or tacts of novel adjective-object pairs as a function of instructional history. The Analysis of Verbal Behavior, 20, 63-76.

Petursdottir, A. I., Carr, J. E., \& Michael, J. (2005). Emergence of mands and tacts of novel objects among preschool children. The Analysis of Verbal Behavior, 21, 59-74.

Ramirez, J., \& Rehfeldt, R. A. (2009). Observational learning and the emergence of symmetry relations in teaching Spanish vocabulary words to typically developing children. Journal of Applied Behavior Analysis, 42(4), 801-805.

Randell, T., \& Remington, B. (2006).Equivalence relations, contextual control, and naming. Journal of the Experimental Analysis of Behavior, 86, 337-354.

Rosa Filho, A., de Rose, J. C., de Souza, D. G., Hanna, E. S., \& Fonseca, M. L. (1998). Aprendendo a ler e a escrever em pequenos passos. Software para pesquisa (Versão 1.0) [Computer software]. São Carlos, SP.

Santos, F. H., \& Bueno, O. F. A. (2003). Validation of the Brazilian children's test of participate pseudo-word repetition in Portuguese speakers aged 4 to 10 years. Brazilian Journal of Medical and Biological Research, 36(15), 33-47.

Sigafoos, J., Doss, S., \& Reichle, J. (1989). Developing mand and tact repertories in persons with severe developmental disabilities using graphic symbols. Research in Developmental Disabilities, 10(2), 183-200.

Sigafoos, J., Reichle, J., Doss, S., Hall, K., \& Pettitt, L. (1990). "Spontaneous" transfer of stimulus control from tact to mand contingencies. Research in Developmental Disabilities, 11(2), 165-176

Skinner, B. F. (1992). Verbal Behavior. New York: AppletonCentury-Crofts. (Original work published 1957)

Toussaint, K. A., \& Tiger, J. H. (2010). Teaching early braille literacy skills within a stimulus equivalence paradigm to children with degenerative visual impairments. Journal of Applied Behavior Analysis, 43(2), 181-194.

Twyman, J. S. (1996). The functional independence of impure mands and tacts of abstract stimulus properties. The Analysis of Verbal Behavior, 13, 1-9. 